This is a revised personal version of the text of the final journal article, which is made available for scholarly purposes only, in accordance with the journal's author permissions. The full citation is:

Banks CJ, Koloskov GB, Lock, AC, Heaven S (2003) "A computer simulation of the oxygen balance in a cold climate winter storage WSP during the critical spring warm-up period", Water Science \& Technology Vol 48 No 2 pp 189-196 @ IWA Publishing 2007 http://www.iwaponline.com/wst/04802/wst048020189.htm

\title{
A computer simulation of the oxygen balance in a cold climate winter storage WSP during the critical spring warm-up period
}

\author{
C. J. Banks*, G. B. Koloskov**, A.C. Lock* and S. Heaven* \\ * Department of Civil \& Environmental Engineering, University of Southampton, Southampton SO17 1BJ, \\ UK (cjb@soton.ac.uk). \\ ** BG Chair of Environmental Technology, Almaty Institute of Power Engineering and \\ Telecommunications, 126 Baytursynov Street, Almaty 480043, Kazakhstan (enviro@ieem.almaty.kz).
}

\begin{abstract}
The paper considers factors that determine the oxygen balance in extreme climate waste stabilisation ponds during the critical spring warm-up period. At this time BOD load on the pond is a maximum, due to accumulation of wastewater under the ice during the winter. The paper describes the operation of a typical cold climate WSP and the events leading to a balanced steady state system as spring develops into summer. A mathematical model to simulate conditions within a batch fed experimental pond over the transient period is described. To model temperature changes in the water body experimental data were fitted to a generalised equation based on diurnal fluctuations in air temperature. The results are plotted in a normalised form and show the diurnal fluctuation and time lapse as the depth of the pond increases. Maximum daily water temperature lags behind maximum light intensity. Bacterial growth is simulated by a Monod kinetic model in which growth rate depends on initial substrate concentration; temperature compensation is applied using a temperature activity coefficient. Oxygen utilisation is calculated from substrate removal. Algal growth rate is more complicated as it is affected by temperature and light availability. Algal oxygen production potential is considered in terms of its primary metabolite yield, which is then used in a Monod equation to estimate the growth rate. The model uses a mass balance approach to determine dissolved oxygen concentration in the pond. The model is still in a simple form but shows reasonable agreement, in terms of events and time lapses, to measured parameters in experimental ponds recovering from ice cover.
\end{abstract}

\section{INTRODUCTION}

Waste stabilisation ponds (WSPs) have been used in extreme climate conditions for the treatment of wastewater since the early 1940s. Originally they were nothing more than primitive lagoons that held wastewater in storage until natural self-purification processes made it fit to discharge into the natural environment. Since then the design of WSP systems has become more sophisticated. In Canada and Alaska there are in excess of 1000 systems for domestic/industrial wastewater treatment representing least $50 \%$ of total wastewater treatment capacity in the region. The use of WSP storage and treatment systems in extreme climates elsewhere has been less common, although research into this method of treatment was carried out and design standards derived for in the countries of the former Soviet Union (Heaven et al., 2002).

\section{Description of an extreme climate WSP}

The most successful extreme climate WSPs are those that use 3 types of ponds and only discharge once every year (Prince et al., 1995). The anaerobic ponds(s) act as first stage treatment and may comprise a number of separate cells operating in series to give a total retention time of 3-10 days. The second stage consists of a facultative pond(s) working in conjunction with the third stage 
maturation/storage pond(s): both these serve to reduce the biochemical oxygen demand (BOD) of the wastewater by the process of biological oxidation. As in conventional WSPs, the system in cold climates relies on the symbiotic relation between bacteria and algae to remove BOD and supply the oxygen necessary for this.

Figure 1 below shows qualitatively the operation of a one-year retention WSP system. There is only one batch discharge of effluent in the autumn, although continuous discharge through the summer months is possible if the effluent quality is satisfactory. The diagram assumes that at the end of the summer period the soluble BOD in the storage/maturation pond is at a very low level (a reasonable assumption considering the extended storage under oxygen-enriched conditions at warm temperatures). When the temperature cools in autumn, algae in both the facultative and maturation ponds begin to settle leaving a body of water that is free of suspended solids; it is generally considered that this response is induced by a fall in water temperature (Prince et al., 1995). At this point the water in the maturation pond is decanted leaving the algal/bacterial sludge and a minimum of bottom waters, thus maximising storage capacity. In some cases part of the water in the facultative pond is also decanted, but this is not common. During the winter wastewater continues to flow through the anaerobic cells (where solids settle) into the facultative pond where ice cover exists and water temperatures beneath this equilibrate at around $4^{\circ} \mathrm{C}$.
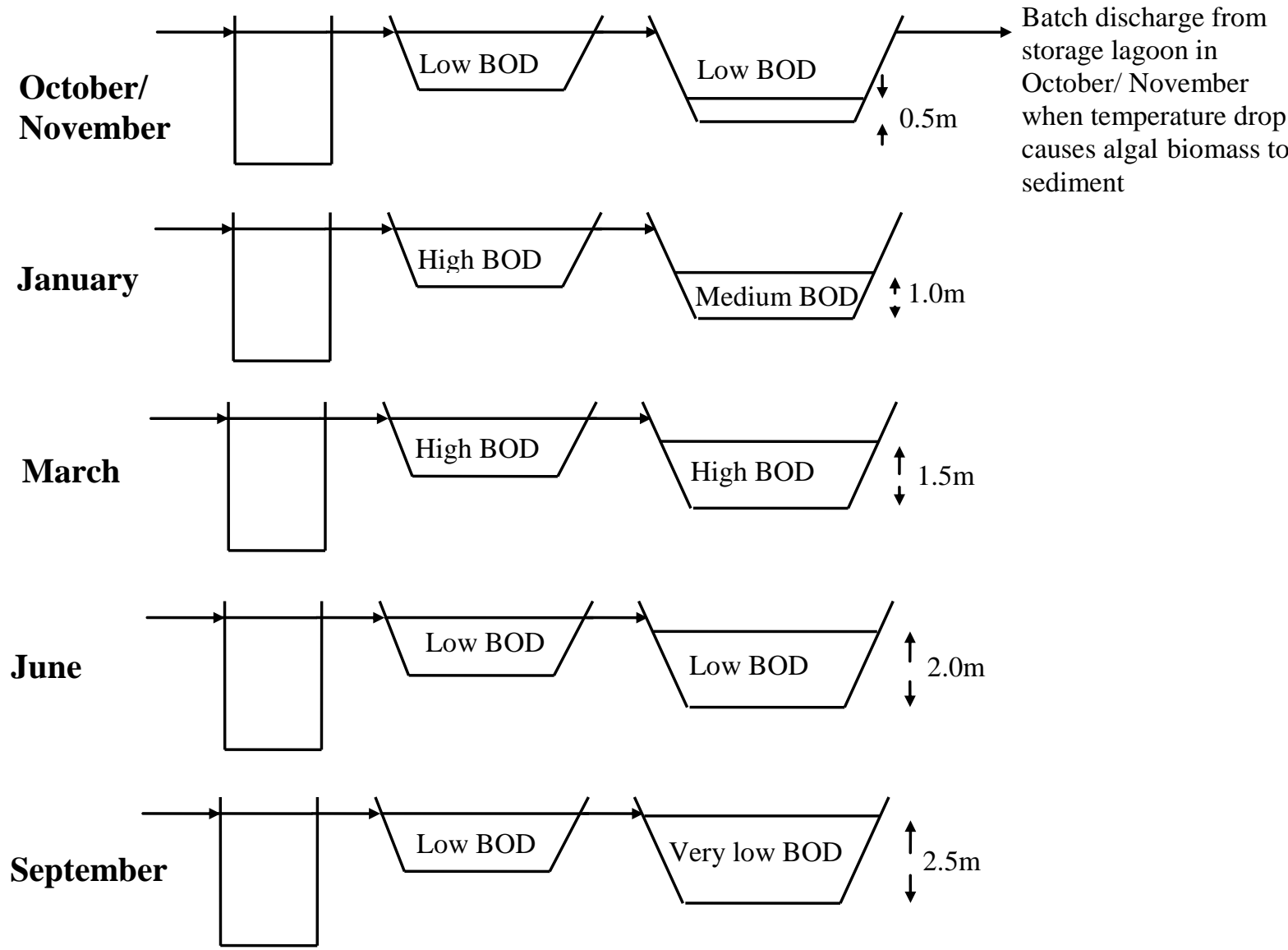

Figure 1 Schematic diagram showing nutrient status in facultative and storage ponds, and water level in the storage pond at different times of the year

The 'clean' water from the facultative pond is diluted out into the storage pond resulting in a situation in spring where the contents of the facultative pond are more or less equal in quality to untreated settled sewage (assuming minimal rates of biological decomposition under ice cover). Those of the maturation pond are similar to partially diluted sewage. Hence in spring, when the ice 
melts, the organic load in the system is at its maximum and dissolved oxygen levels are probably at their minimum. It is at this point (if any) that the system is likely to be odoriferous.

During the spring 'warm up' period the BOD in both the facultative and maturation ponds will start to be reduced as a result of aerobic heterotrophic microbial utilisation of the dissolved organic matter. Oxygen for this will be supplied by the population explosion of algae that grow photosynthetically at the expense of macronutrients and inorganic carbon sources. During this time the facultative pond will continue to receive settled wastewater whilst the maturation pond will receive a reduced organic load due to its influent having been 'pre-treated' through the facultative pond. In this spring period, both the facultative and maturation ponds will be operating in 'facultative mode' with an excess of soluble organic carbon and nutrients. As spring turns to summer the depth of water in the maturation pond will increase above the optimum for a facultative pond. By this time, however, the organic load on it will be very low, and it will start to function as a maturation pond reducing soluble BOD to low levels. Depending upon temperature, initial organic load and other factors both the facultative and maturation ponds should reach a steady state by June and continue to operate throughout the summer period in a conventional manner. By the end of the summer the soluble BOD in the maturation pond will be very low (possibly between 5-15 $\mathrm{mg}^{-1}$ ) resulting in a high quality autumn discharge.

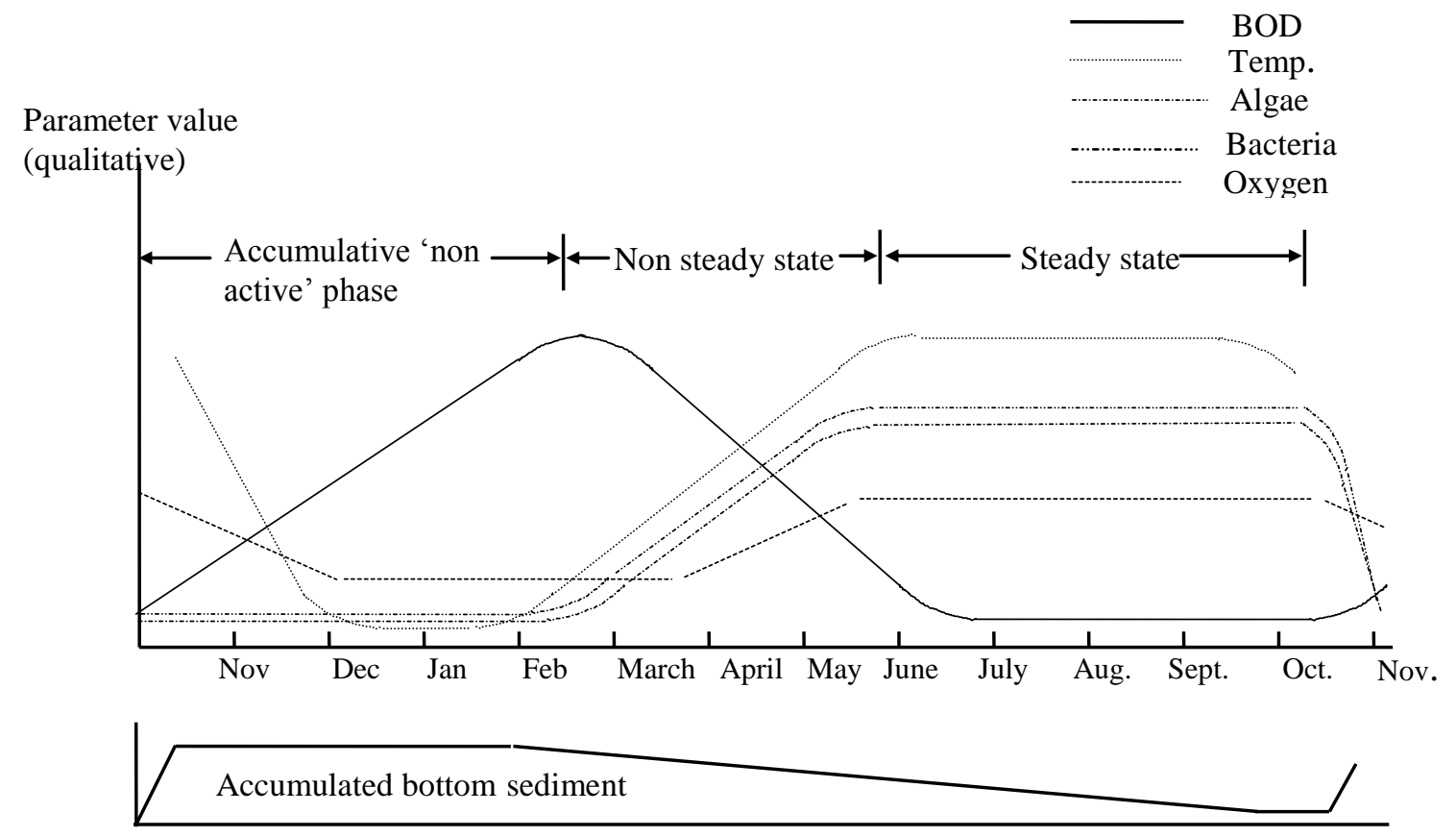

Figure 2 Qualitative graphical description of events in a cold climate facultative pond

Figure 2 qualitatively depicts the fate of key parameters in the facultative pond during the 12-month period. These are descriptively divided into three phases: 'accumulation' where BOD load is added but not destroyed; 'non steady state' where BOD load is progressively destroyed as temperature and microbial numbers (algal and bacterial) increase; and 'steady state' where BOD is consistently low, microbial numbers are in equilibrium, and summer temperatures are more or less constant.

The critical phase appears to be during the 'non steady state' period as the initial organic load is high, the oxygen production potential (algal numbers) is at its lowest, and the potential for bacterial growth (both aerobically or anaerobically) is at its maximum. If the initial load is such that the rate of oxygen depletion is greater than the rate of replenishment then the system will be predominantly anaerobic during this phase leading to odours and lower rates of reaction. If the initial load, and continuing input, is low then the rate of oxygen replenishment may exceed the oxygen demand and 
the system will become oxygen saturated. In terms of treatment this latter state of affairs will do no harm but it does represent a process inefficiency as the system is larger than it needs to be.

\section{MODELLING}

The current work is an attempt to model the potential oxygen balance in a facultative pond during the non steady state spring warm-up period. In effect the microbial systems in a cold climate pond are inactivated during the winter period where water temperature drops to freezing in the surface water and close to freezing throughout the rest of the water body. Any photosynthetic activity will also cease as light penetration beneath the ice is minimal due to a snow covering. Relatively little is known about the survival of the microorganisms in the pond over this period, and hence their effectiveness as an inoculum for fresh growth once there is free water and light penetration.

It is assumed that the survival of macro-invertebrates, such as fly larvae, that inhabit the water column is very restricted and that these will invade the system only when conditions are favourable in the late spring and early summer. Due to the relatively slow growth rates of these secondary feeders it is also assumed that their contribution to the removal process during spring is negligible and that the system is dominated by phototrophic algae and heterotrophic bacteria, algae and protozoa. The system in early spring is thus microbial and the model considers only the growth, substrate utilisation, and photosynthetic activities of microbes. These activities are influenced by temperature, substrate availability, and light, which are all in a dynamic state during the non steady state condition as depicted in Figure 2.

Development of a temperature model: Temperature in the water column is influenced by air temperature and direct irradiance of the surface water. Experimental data from many sources for shallow lakes and ponds, where a thermocline does not develop, shows a gradual reduction in temperature with depth. Our experimental observations show that daily air temperature fluctuations are mirrored by changes in water temperature, but with a slight lag and an increasing damping effect with increasing depth. The daily air and water temperature data has a characteristic sinusoidal form (Figure 3), which is applicable to any daily temperature range and can be approximated for specific locations by the following equation:

$$
f(t)=a_{1} \sin \left(\frac{2 \pi}{T_{1}}\left(t-t_{10}\right)\right)+a_{2} \sin \left(\frac{2 \pi}{T_{2}}\left(t-t_{20}\right)\right)+b
$$

Values can be derived for $\mathrm{a}_{1}, \mathrm{t}_{10}, \mathrm{a}_{2}, \mathrm{t}_{20}$, and $\mathrm{b}$ using initial values of 24 for $\mathrm{T} 1$ and 12 for $\mathrm{T} 2$. Examples for Almaty, Kazakhstan are given in Figures 3 and 4 with normalised values. These profiles are generally applicable unless extreme changes occur over a short period. Variation in air temperature over longer periods, for example a year, can also be fitted to the same equation using a different set of parameter values. Knowing daily average air temperatures, it is therefore possible to simulate the average temperature behaviour at different depths in the water column as in Figure 5.

Biological growth and oxygen balance model. The model is based on Buhr and Miller (1983) and considers the growth of both bacteria and algae. It uses the Monod equation to relate the specific growth rate of a microbial population and the limiting substrate concentration (Monod, 1949).

$\mu_{B}=\frac{\mu_{\max } S}{K_{S}+S}$

For bacterial growth there are two important components: substrate and oxygen, so the growth rate $\mu$ is expressed as the product of two Monod equations: 
$\mu_{B}=\mu_{\max B} \cdot \frac{S}{K_{s}+S} \cdot \frac{O_{2}}{K_{O_{2}}+O_{2}}$

where $\mu_{\mathrm{B}}=$ bacterial specific growth rate in days ${ }^{-1} ; \mu_{\max }=$ maximum bacterial specific growth rate in days ${ }^{-1} ; \mathrm{S}=$ substrate concentration in $\mathrm{mg} \mathrm{l}^{-1} ; \mathrm{K}_{\mathrm{s}}=$ half saturation substrate concentration in $\mathrm{mg}$ $\mathrm{BOD} \mathrm{l}^{-1} ; \mathrm{K}_{\mathrm{O}_{2}}=$ half saturation oxygen concentration in $\mathrm{mg} \mathrm{l}^{-1}$.

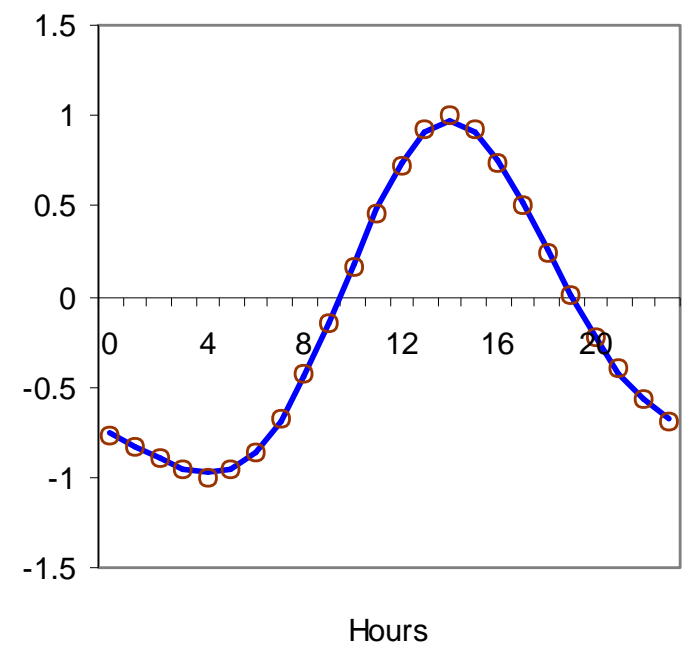

○ Average

Figure 3 Almaty hourly air temperature (normalised)

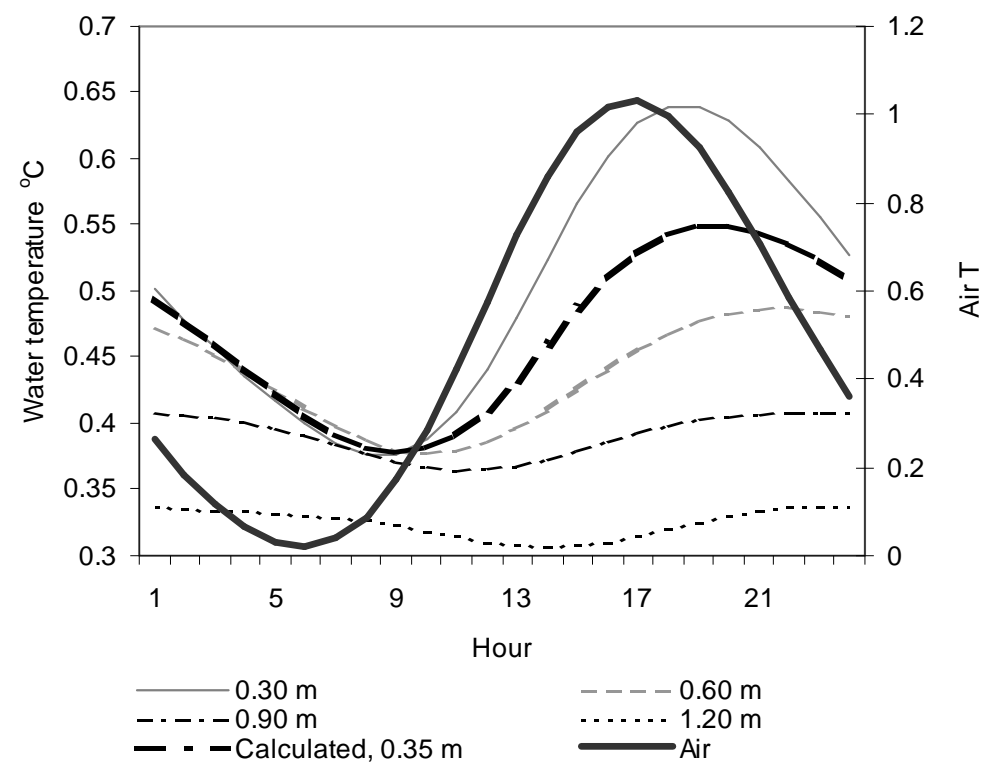

Figure 4 Average hourly water temperature (normalised to [0..1] range). Almaty Summer 1999 data

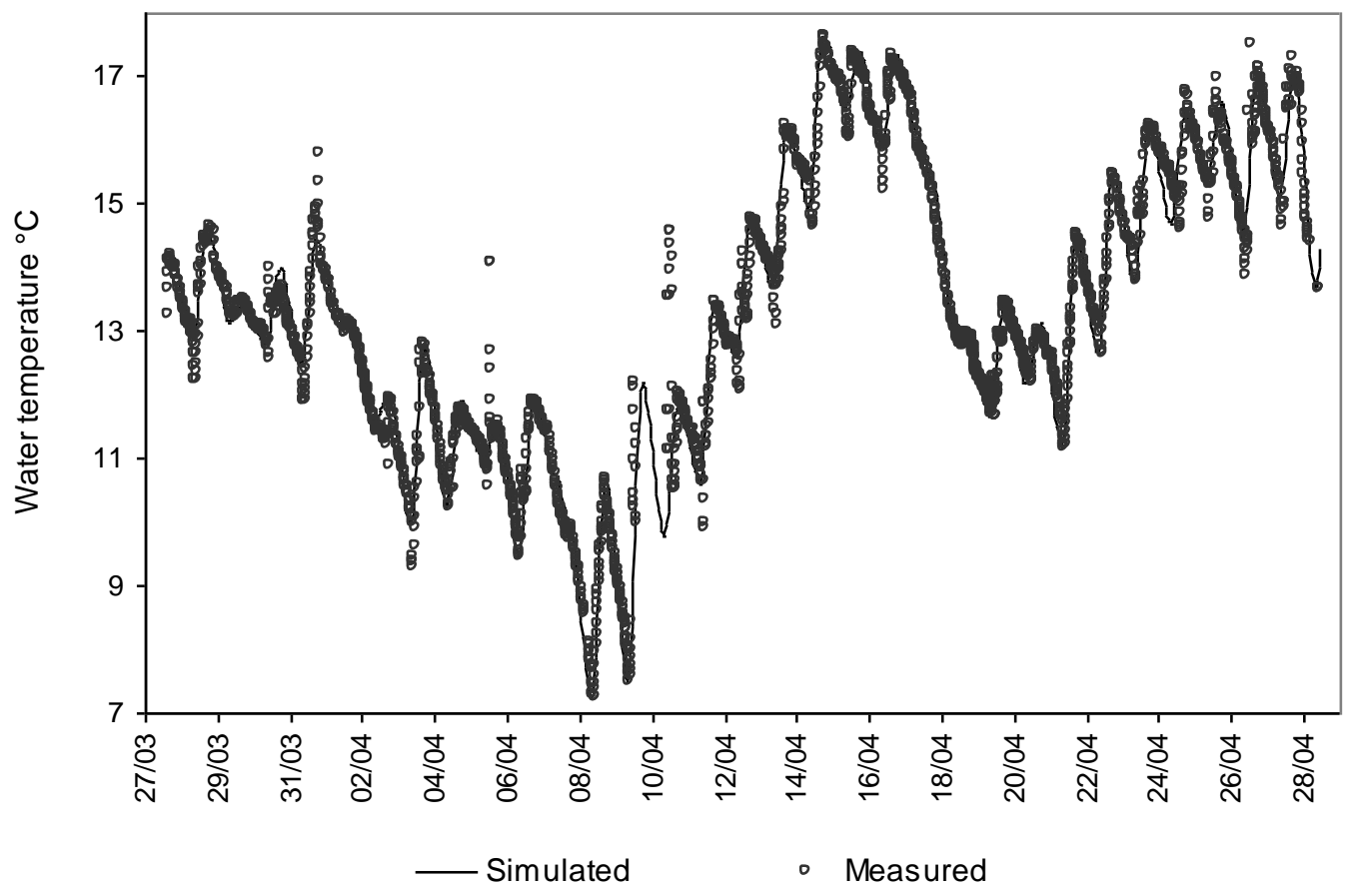

Figure 5 Comparison of measured and simulated data for Almaty experimental pond 
The rate of change of substrate concentration depends on substrate inflow, outflow and bacterial consumption and is given by

$$
\frac{d S}{d t}=\frac{F}{V}\left(S_{o}-S_{e}\right)-\left(\mu_{B} \frac{X}{Y}\right)
$$

where $\mathrm{S}=$ substrate concentration in $\mathrm{mg}^{-1} ; \mathrm{F}=$ flow to reactor in 1 day $^{-1} ; \mathrm{V}=$ reactor volume in 1 ; $\mathrm{S}_{\mathrm{o}}=$ influent or initial substrate concentration in $\mathrm{mg}^{-1} ; \mathrm{S}_{\mathrm{e}}=$ effluent or final substrate concentration in $\mathrm{mg} \mathrm{l}^{-1} ; \mathrm{X}=$ bacterial biomass density in $\mathrm{mg} \mathrm{l}^{-1} ; \mathrm{Y}=$ yield coefficient for bacteria in $\mathrm{mg} \mathrm{mg}^{-1}$. The rate of change of bacterial biomass density is dependent on inflow to and outflow from the reactor, and growth and die-off within the reactor, and is given by

$$
\frac{d X}{d t}=\frac{F}{V}\left(X_{o}-X_{e}\right)+\mu_{B} X-k_{D B} X
$$

where $\mathrm{k}_{\mathrm{DB}}=$ endogenous decay coefficient for bacteria in day $^{-1}, \mathrm{X}_{\mathrm{o}}=$ influent bacterial biomass concentration in $\mathrm{mg} \mathrm{l}^{-1} ; \mathrm{X}_{\mathrm{e}}=$ effluent bacterial biomass concentration in $\mathrm{mg} \mathrm{l}^{-1}$.

For algal growth, the 'substrates' are $\mathrm{CO}_{2}$ and light. The Monod equation is used for $\mathrm{CO}_{2}$ (Kayombo et al., 2000), while the effect of light is modelled by multiplying $\mu_{\max }$ by two functions. The function $\mathrm{L}(\mathrm{t})$ allows for the variation in light intensity during the day, and can be modelled by theoretical or experimental data. Light intensity is also reduced by the presence of suspended solids in the water, in accordance with an exponential relationship. The amount of light scattered and absorbed depends on the nature of the suspended solids (Kirk, 1994; Curtis et al., 1994). The algal growth rate is therefore given by

$\mu_{A}=\mu_{\max A} \frac{C O_{2}}{k_{C}+C O_{2}} \cdot e^{-F_{D}\left(S_{D} \cdot S+B_{D} \cdot X+A_{D} \cdot A\right)} \cdot L(t)$

where $\mu_{\mathrm{A}}=$ algal specific growth rate in days ${ }^{-1} ; \mu_{\max }=$ maximum algal specific growth rate, days ${ }^{-1}$; $\mathrm{CO}_{2}=\mathrm{CO}_{2}$ concentration in $\mathrm{mg} \mathrm{l}^{-1} ; \mathrm{K}_{\mathrm{c}}=\mathrm{CO}_{2}$ half saturation concentration in $\mathrm{mg} \mathrm{l}^{-1} ; \mathrm{F}_{\mathrm{D}}=$ a factor representing scattering and absorption in $1 \mathrm{mg}^{-1} ; \mathrm{S}_{\mathrm{D}}=$ substrate density factor; $\mathrm{B}_{\mathrm{D}}=$ bacterial density factor; $A_{D}=$ algal density factor (representing the relative influence of each component).

The rate of oxygen production is a function of the production of new algal and bacterial biomass

$$
\frac{d O_{2}}{d t}=\frac{F}{V}\left(O_{2 o}-O_{2 e}\right)+Y_{O A} \mu_{A} A-Y_{O B} \mu_{B} X
$$

where $\mathrm{O}_{2 \mathrm{o}}=$ influent oxygen concentration in $\mathrm{mg}^{-1} ; \mathrm{O}_{2 \mathrm{e}}=$ effluent oxygen concentration in $\mathrm{mg}^{-}$ $1 ; \mathrm{Y}_{\mathrm{OA}}=$ oxygen production yield coefficient for algae in $\mathrm{mg}^{-1} ; \mathrm{Y}_{\mathrm{OB}}=$ oxygen consumption yield coefficient for bacteria in $\mathrm{mg}^{-1}$. The rate of $\mathrm{CO}_{2}$ production is related to the rate of oxygen consumption and is similarly a function of the rate of production of new biomass

$$
\frac{d C O_{2}}{d t}=\frac{F}{V}\left(C O_{2 O}-C O_{2 e}\right)+Y_{c B} \mu_{B} X-Y_{C A} \mu_{A} A
$$

where $\mathrm{CO}_{2 \mathrm{o}}=$ influent $\mathrm{CO}_{2}$ concentration in $\mathrm{mg} \mathrm{l}^{-1} ; \mathrm{CO}_{2 \mathrm{e}}=$ effluent $\mathrm{CO}_{2}$ concentration in $\mathrm{mg} \mathrm{l^{- }}$ $1 ; \mathrm{Y}_{\mathrm{CB}}=\mathrm{CO}_{2}$ production yield coefficient for bacteria in $\mathrm{mg}^{-1} ; \mathrm{Y}_{\mathrm{CA}}=\mathrm{CO}_{2}$ consumption yield coefficient for algae in $\mathrm{mg}^{-1}$.

The rates of growth of bacteria and algae are highly temperature-dependent. The model takes this into account by adjusting values of $\mu_{\max }$ according to the following equation:

$$
\mu_{\max _{(t)}}=\mu_{\max _{20}} \theta^{(t-20)}
$$


The user can choose typical values for $\mu_{\max }$ and $\theta$ from the literature, or can input experimental data. The model requires input values for the coefficients defined above. The user enters the start date and time, the duration of the simulation and the time step size. The model can operate in both batch feeding and continuous flow modes. In batch mode it checks at the start of each time step to see if feeding is scheduled. For each time step the average water temperature is updated and the model checks the current value of all components. It calculates current values of $\mu$ for algae and bacteria with equation 9. It then calculates the change in substrate concentration, bacterial biomass, algal biomass, oxygen and $\mathrm{CO}_{2}$ consumption and production using equations 3-8. The change in each value is compared with the current value to check that a negative total has not been generated. If a negative total occurs, it is reset to zero. For example, if the initial oxygen concentration is $2 \mathrm{mg}^{-1}$ and the calculated oxygen consumption in the given time period is $4 \mathrm{mg} \mathrm{l}^{-1}$, the demand cannot be satisfied so it is assumed that all the available oxygen is consumed and a correspondingly smaller amount of substrate is utilised. The model then recalculates the amount of substrate and the yield of cells.

\section{RESULTS AND DISCUSSION}

The model was run to simulate the batch operation of a small-scale experimental WSP in Almaty during the spring warm-up period. The experimental data for this pond and the mode of operation are reported in Pak et al. (2002), although some assumptions are made in the modelling as to the initial substrate concentration in the pond. Experimental data suggested that this was quite high due to remobilisation of soluble material from the bottom sediments, despite the pond not receiving wastewater since ice formation in late November of the previous year. The model parameters were thus set to give an initial substrate concentration of $500 \mathrm{mg} \mathrm{l}^{-1}$ and a daily feed concentration of 300 $\mathrm{mg}^{-1}$ at a 30-day retention time. Values for the constants used in the model were those suggested by Buhr and Miller (1983) with the exception of the value for $\mu_{\max }$ and the temperature coefficient $\theta$ which were taken from the work of Bartosh et al. (2002); there was little difference, however, between these and the earlier work. The temperature simulation in the model used the approach described earlier in this work and the temperature profile as shown in Figure 5. Values for the initial numbers of bacteria and algae are difficult to ascertain experimentally because the viability of organisms remaining after ice formation is unknown. Values of $10 \mathrm{mg} \mathrm{l}^{-1}$ were used for both bacteria and algae, and this appeared to give a reasonable approximation to observed values.

Table 1 Model parameters used in simulation

\begin{tabular}{llll}
\hline Parameter & InFlow & Pond & Unit \\
\hline Volume & 26 & 750 & litres \\
Algae & 0.00001 & 10 & $\mathrm{mg} \mathrm{l}^{-1}$ \\
Bacteria & 0.00001 & 10 & $\mathrm{mg} \mathrm{l}^{-1}$ \\
Substrate & 200 & 500 & $\mathrm{mg} \mathrm{l}^{-1}$ \\
$\mathrm{CO}_{2}$ & 2 & 4.67 & $\mathrm{mg} \mathrm{l}^{-1}$ \\
Oxygen & 2 & 1 & $\mathrm{mg} \mathrm{l}^{-1}$ \\
$\mathrm{~N}$ & 7 & 7 & $\mathrm{mg} \mathrm{l}^{-1}$ \\
\hline
\end{tabular}

\begin{tabular}{|c|c|c|}
\hline Constants & Values & Units \\
\hline$\mu_{\max A}$ & 1.13 & days $^{-1}$ \\
\hline$\mu_{\max B}$ & 4.95 & days $^{-1}$ \\
\hline Y & 0.4 & (mg bacterial cells).(mg BOD consumed $)^{-1}$ \\
\hline $\mathrm{Y}_{\mathrm{CA}}$ & 2.1824 & $\left(\mathrm{mg} \mathrm{CO}{ }_{2}\right.$ consumed $) \cdot(\mathrm{mg} \text { algae })^{-1}$ \\
\hline$Y_{O A}$ & 1.5872 & $\left(\mathrm{mg} \mathrm{O}_{2}\right.$ produced $) .(\mathrm{mg} \text { algae })^{-1}$ \\
\hline $\mathrm{Y}_{\mathrm{CB}}$ & 3.432 & $\left(\mathrm{mg} \mathrm{CO} \mathrm{CO}_{2}\right.$ produced $) .(\mathrm{mg} \text { bacteria })^{-1}$ \\
\hline $\mathrm{Y}_{\mathrm{OB}}$ & 2.496 & $\left(\mathrm{mg} \mathrm{O}_{2}\right.$ consumed $) .(\mathrm{mg} \text { bacteria })^{-1}$ \\
\hline $\mathrm{K}_{\mathrm{S}}$ & 150 & $\mathrm{mg} \mathrm{BOD} \mathrm{I}^{-1}$ \\
\hline $\mathrm{K}_{\mathrm{O} 2}$ & 0.128 & $\mathrm{mg} \mathrm{l}^{-1}$ \\
\hline $\mathrm{K}_{\mathrm{C}}$ & 0.044 & $\mathrm{mg} \mathrm{l}^{-1}$ \\
\hline$K_{D A}$ & 0.05 & 1 days $^{-1}$ \\
\hline $\mathrm{K}_{\mathrm{DB}}$ & 0.1 & 1 days $^{-1}$ \\
\hline
\end{tabular}

It is clear that temperature has a substantial effect on degradation with a low rate occurring in the first period up until 14 April and then an acceleration in rate as the temperature increased above $15^{\circ} \mathrm{C}$ eventually rising to a daily mean of $25^{\circ} \mathrm{C}$. Oxygen concentrations were limited until almost the 
middle of May and substrate concentration levels did not reach a steady state until about the same time. The model equilibrium time was earlier than was observed in practice, where the pond was found to reach steady state in the middle of June. The other difference lies in the final steady state concentrations of algal numbers, where the model predicts higher values than were found in reality. This may account for the more rapid BOD removal in the model. Adjustment of model constants could reduce these levels to give a better fit. This will be done in later sensitivity studies, but has not been attempted here: the values of the constants used are those typically found in reference books and reported by other researchers.

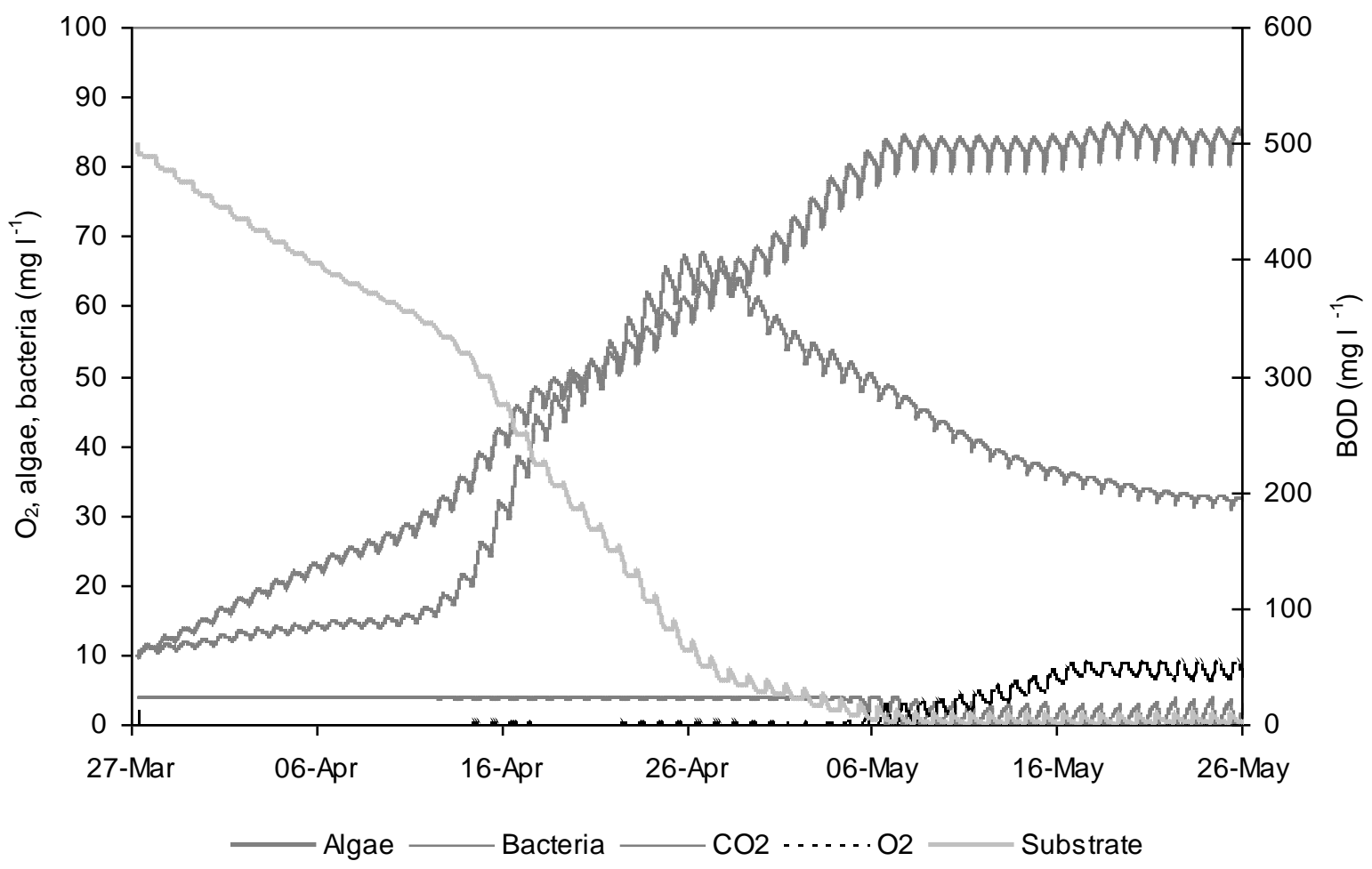

Figure 6 Results of a typical model simulation run for experimental small-scale WSP in Almaty

\section{CONCLUSIONS}

The fact that there is reasonable agreement without any 'fitting' of values to experimental data derived from the ponds indicates that the model is inherently robust.

The model is still in its development stage and at present operates as a single cell in which the concentrations of substrate and organisms are uniform throughout. It is our intention to refine the model to adopt a multiple cell approach in which changes can be predicted at different depths in the pond. This will require further work on understanding and modelling the light penetration within the system and the mass transfer of gases and nutrients between different depth zones. The model could also be adapted to take into account of plug flow conditions by using cells in series with mass transfer in the longitudinal plane.

\section{Acknowledgements}

The authors would like to acknowledge the support of EU INCO-Copernicus Project CT98-0144, INTAS KZ 96-1864, and of the BG Foundation, which allowed them to carry out this work. 


\section{References}

Bartosh, Y., Banks, C.J., Smallman, D. (2002). An evaluation of growth kinetics and oxygen production of two typical green algae (Chlorella and Scenedesmus) grown under controlled laboratory conditions. In: Proc. 5th International IWA conference on WSPs Auckland 2-5 April 2002. IWA. (In press) .

Buhr, H.O. and Miller, S.B. (1983). A dynamic model of the high-rate algal-bacterial wastewater treatment pond. Wat. Res. 17, 29-37.

Curtis, T.P., Mara, D.D., Dixo, N.G.H., Silva, S.A. (1994). Light Penetration in Waste Stabilization Ponds. Wat. Res. 28 (5) 1031-1038.

Heaven, S., Lock, A.C. Pak, L.N., Rspaev, M.K. (2002) Waste Stabilisation ponds in extreme continental climates: a comparison of design methods from the USA, Canada, northern Europe and the former Soviet Union. In: Proc. 5th International IWA conference on WSPs Auckland 2-5 April 2002. IWA. (In press).

Kayombo, S., Mbwette, T.S.A., Mayo, A.W., Katima, J.H.Y., Jorgensen, S.E. (2000). Modelling diurnal variation of dissolved oxygen in waste stabilization ponds. Ecological Modelling 127(1) 21-31.

Kirk, J.T.O. (1994). Light and photosynthesis in aquatic ecosystems. Cambridge University Press, Cambridge.

Monod, J. (1949) The growth of bacterial cultures. Ann. Rev. Microbiol. 3, 371-394.

Pak, L.N., Rspaev, M.K., Banks, C.J. (2002). Springtime acclimatisation of a winter ice-covered waste stabilisation pond: operational data from 4 experimental units. In: Proc. 5th International IWA conference on WSPs Auckland 2-5 April 2002. IWA. (In press).

Prince, D.S., Smith, D.W., Stanley, S.J. (1995). Performance of lagoons experiencing seasonal ice cover. Water Environment Res. 67 (3) 318-326. 